\title{
Kongo Atlantic Body Language
}

\section{Barbaro Martinez-Ruiz}

\section{(2) OpenEdition}

\section{Journals}

Electronic version

URL: http://journals.openedition.org/actesbranly/462

DOI: 10.4000/actesbranly.462

ISSN: 2105-2735

\section{Publisher}

Musée du quai Branly Jacques Chirac

\section{Electronic reference}

Barbaro Martinez-Ruiz, « Kongo Atlantic Body Language », Les actes de colloques du musée du quai Branly Jacques Chirac [Online], 2 | 2009, Online since 08 December 2009, connection on 08 September 2020. URL: http://journals.openedition.org/actesbranly/462 ; DOI : https://doi.org/10.4000/ actesbranly.462

This text was automatically generated on 8 September 2020

(c) Tous droits réservés 


\title{
Kongo Atlantic Body Language
}

\author{
Barbaro Martinez-Ruiz
}

1 Together with cosmology, two-dimensional writing, religious objects, and sacred songs, gestures and other modes of body expression form graphic writing systems that catalog, interpret and pass along complex codes of cultural knowledge. Far more than mere aesthetic additions to verbal communication, gestures among the Bakongo are a form of language and a mode of communication in their own right. I have attempted to demonstrate in my discussion of the other forms of graphic writing that the roots of Kongo graphic communication stretch millennia back in time and the systems seeds have spread nearly as far to take hold in Cuba and other parts of the Americas. I seek to demonstrate here, through a detailed exploration of ancient and contemporary gestural expressions, that similar continuity exists between past and present, and throughout Bakongo culture.

2 I will argue that the images found in ancient sites document visual repertoires that served as the foundation of visual syntax, as the language of art, for the major cultures in Central Africa. I will base my arguments on cave paintings discovered in the Luvo cave system and other rupestrian sites in Angola. This physical record of the past will be compared with visual documentation of historical encounters in the region, with gestures depicted in three-dimensional Kongo art, and with contemporary body language used by the Bakongo in Zaire Province, Angola. In tracing the development of Kongo gestural code, I will show consistency in form and meaning over time and illustrate the central importance of gesture as a communicative tool.

3 In discussing body communication among the Bakongo, I am working from the following definition of gesture offered by the linguist Nancy Bonvillain in Language, Culture, and Communication.

[Gesture is] composed of formally distinct features that co-occur in various combinations... It employs four basic kinds of articulatory parameters in the production of signs. These include: (1) hand configuration: how the hands are shaped; (2) place of articulation: where a sign is formed in relation to signer's body; (3) movement of hands in space, and (4) orientation of hands in relation to the body ${ }^{1}$. 

consideration the positioning of the entire body in the context of sign formation. With this broader view, several hundred body poses and gestural movements are implicated, each invoking an array of cultural meanings. Further complicating a study of communicative body language is the fact that the cultural meaning of a gesture can be context specific so that a sign made while interacting on the street may imply a different or deeper meaning if used while worshipping inside a Church or between members of a religious fraternity. This complexity uniquely positions body signs in Central Africa and the Kongo diaspora to operate as poetry, as special verbal formulas composed of cultural and religious meaning at given moment and transmitted according to cultural necessity.

It is in this sense that gestures most closely approximate oral tradition in their role and development. Like their oral cousins, gestures are visual messages that encode the lessons and histories of communities, preserving memory across generations. ${ }^{2}$ Also relevant to the connection between oral and gestural traditions is Jan Vansina's definition of communication as both a process and a product. ${ }^{3}$ Gestures are undeniably a product of the cultural need to express what words alone cannot. Like other communicative products such as stories or songs, gestures entail a process in the sense that acts are performed, created through a series of movements learned by each successive generation. Furthermore, each subsequent generation, within its unique historical and social circumstances will codify and add meaning to the gestures it inherits, simultaneously reflecting and impacting cultural development and allowing reinterpretation of its experience.

6 Betty and Franz Bauml, in their dictionary of gesture, establish a dichotomous frame for the understanding of physical language. On the one hand, they write of a system of communication that implies a standardization of meaning and form. On the other hand, they correctly point out that artistic expression is by definition subjective, interpretive, and an integration of fantasy and reality. In studying gestural communication, it is imperative to understand the ways in which these two modes interact and are understood by those that use them. Although much of what is expressed is subjective in substance, body language that it standardized within a culture enables concepts to be presented in an objective, easily understood manner.

7 In one of the earliest works on the subject, the 1981 book The Four Moments of The Sun by Robert Farris Thompson, concentrated on specific traits in Kongo culture and included a discussion of Kongo gestures. Thompson explained the importance of gestures, writing "The richness and expressive depth of allusion which designate these forms are bodily equivalents to the imperatives of memory and correct application which distinguishes the usage of proverbs and songs in the law courts of Kongo." ${ }^{4}$ Robert Farris Thompson built upon his work on gestures in The Four Moments of the Sun in 2003 with Le Geste Kongo. In both works, Thompson makes a strong argument about the way the gestural traditions in Central African civilization are a means by which to better understand social and aesthetic realities. Gestures allow examination of overlapping meanings affected by cultural, historical and political circumstances such as slavery, colonialism, independence, cultural transference, war, and religious intolerance in the region. Thompson makes the argument for the importance of gestures by establishing a relationship between body language and the organizing physical principles in other artistic production, such as that of Niombo cloth figures, stone statues, ancestor shrines, 
grave decoration and funeral art, military art such as swords, and religious art like Min'kisi and crucifixes.

\section{Kongo Understanding of Body and Gesture}

Before going further into a detailed discussion of specific Kongo gestures, it will be helpful to briefly explore the way in which the human body and its capacity to communicate is understood by the Bakongo. In this sense, K. K. Bunseki FuKiau's manuscript Kongo Religious Philosophy is another valuable source of information on Kongo gesture. Bunseki conceptualizes gestural form in the center of Kongo philosophy and cosmogony and argues that gestures and written signs are part of a single codified approach to communication and meaning. Among the Bakongo currently living in and around Mbanza Kongo, the concept of gesture falls within the notion of body communication. Residents of Mbanza Kongo conceptualize gesture in three ways. All three categories of gesture are defined in terms of communication and are essentially differentiated by the receiver of said communication on basis of the cultural context and social function in which the gesture is made.

The first category of gesture is called Ndinga dia Nitu literally meaning body language used for every day communication among peoples in cities, villages or along roads. ${ }^{5}$ Aesthetic expression is mostimportant for this type of gesture. The gestural aesthetic refers to a narrative tradition, which enriches the literary culture, and represents the mythical world through symbolic gestures.

11 The second category of is called Bisinsu diaKinkulu, and implies communication with spirits, ancestors and elders. ${ }^{6}$ Of greatest importance this category is metaphysical and philosophical knowledge and the way these are used for instruction through initiation, for transmission of news, orders and oral histories, and for the sending of reports of spiritual evidence. The gestures become a form of spatial writing complemented by sounds, phrases, or secret rhythms which, when used within ritual performance, invoke powerful spiritual forces from nature and the cosmos. This form of communication also has an educational function among the practitioners, which permits content enrichment.

The third category is called Dumuka. Not quite definable as traditional gesture, this type of body expression involves broader physical motion. ${ }^{7}$ Religious in characher, Dumuka means to jump high enough to reach the ancestors, ask for spiritual guidance and receive wisdom. It is believed impossible in some religious groups in Mbanza Kongo to receive this kind of spiritual education while standing, instead the practitioner must be floating in the air. Although somewhat removed from traditional gestures, dumuka is conceptualized by the Bakongo in terms similar to the first two categories. Beyond these three categories, any thinking about Bakongo understandings and uses of gestures must consider the context of Kongo religious practice. The concept of gesture as a type of powerful scripture in space is present in most of the religious practices across Africa that incorporate multiple layers of 'objects' including three dimensional figures, drawings, physical poses, and temporal gestures or movements. These layers, once activated, collectively document the particular experience and the broader tradition, serving as containers of knowledge able to convey meaning. In understanding the roles of these layers, and the manner of their union, it is crucial to recognize the fluidity of meaning, form, and function. The philosophical knowledge they collectively formulate is dynamic and responsive and includes "such issues as the possibility of priority knowledge, the nature of memory and abstract thought, and the 
reality of the external world." ${ }^{\prime}$ In addition, the traditions incorporate cosmological renderings of the origin of life and cosmogonical understandings of the creation of humans and God.

\section{Reading the Vocabulary of the Body}

The prominence, importance, and range of body language in Mbanza Kongo today has not spontaneously developed. To the contrary, physical evidence suggests that the region's gestural history stretches over several thousands of years. The earliest sources of body language vocabulary are contained in the ancient rupestrian art found throughout the Central African region. As discussed in chapter 3, the precise age of all of the archeological sites is unknown, but they range from two to eight thousand years old. Two things are striking about the rupestrian images; the fact that gestures play such a prominent role in the cave paintings, and the strong similarities seen across both the range of ancient sites and contemporary gestural practices in the area.

In the following examples, I trace through a selection of important gestures seen from ancient caves to present day Angola and in the Diaspora. The detailed explanations of the gestures' meanings are designed to illustrate the complexity of this type of graphic symbol and emphasize the important role of gestures and body poses in communication. Plate 1 and 2 depict a human form with the upper part of the body in the shape of a cross. This is a typical representation from Luvo sites that combines elements of ideographic and pictographic depiction with simply drawn design and bold or dark drawing inside the single symbols.

Plates 1 and 2. Luvo rupestrian painting. Adapted from Paul Raymaekers and Hendrik van Moorsel, 1962.

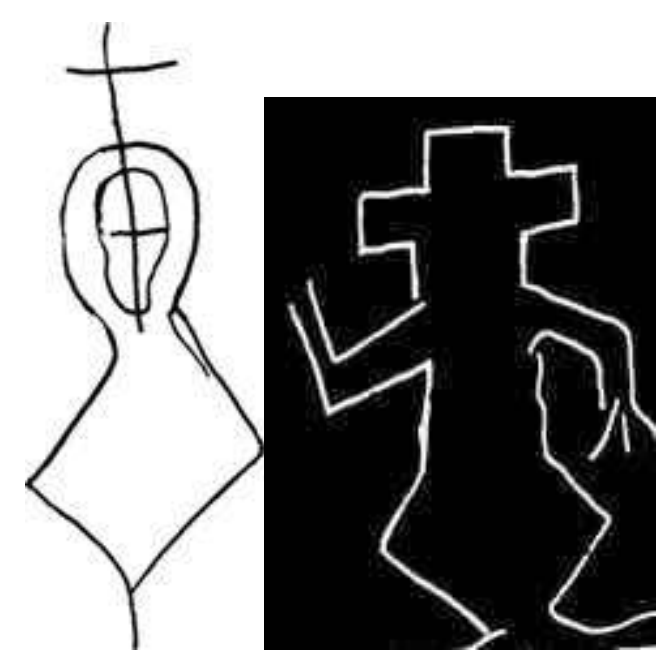

16 As I will show, the two depictions have much in common, but can also be distinguished in critical ways. The fact that both figures are found in the same cave presents some difficulty in how to interpret them and their relation will remain a mystery for us. Plate 1 is an ideographic depiction of a human body combined with the sign of a cross. In this case, the cross becomes the upper part of the body while the lower part is represented by a tadi, or diamond. Plate 2 also contains a tadi, although in more abstract form. The tadi has a variety of meanings for the Bakongo, depending on the design. In this example, its basic meaning is a symbol of bakulu (ancestors). According to traditional sources in Zaire province, Angola, the conceptualization of tadi comes straight from cosmogony. When a diamond is found, it is because an ancestor is transformed into a 
rock and is flashing from deep inside the rain forest. The light becomes the signal of the ancestor to a single person. The meaning of Tadi goes far beyond a single literal meaning to have implications for religious practices and philosophy. Tadi's powerful four corners are commonly referred to in Kongo oral literature. For example:

O nzá knonko kena

Ovo zaya kaka e nkonko za nzá, o zingidi kw’aku.

The world has corners

When you know these corners, you will live forever 9

17 In plate 2, the upper body is depicted with the right arm raised and the left arm pointing down, a pose called Lusaso Seko. These arms "call for attention or make a connection with God," ${ }^{10}$ as the fingers of the right hand stretch as sign of minienie (sun rays $)^{11}$ that travel through the body down into the ground as sign of connection between heaven and earth.

Fig. 1. Ntino Nzaku Nevunda making the same gesture that he called Fundisua kua Ludi, Mbanza Kongo.

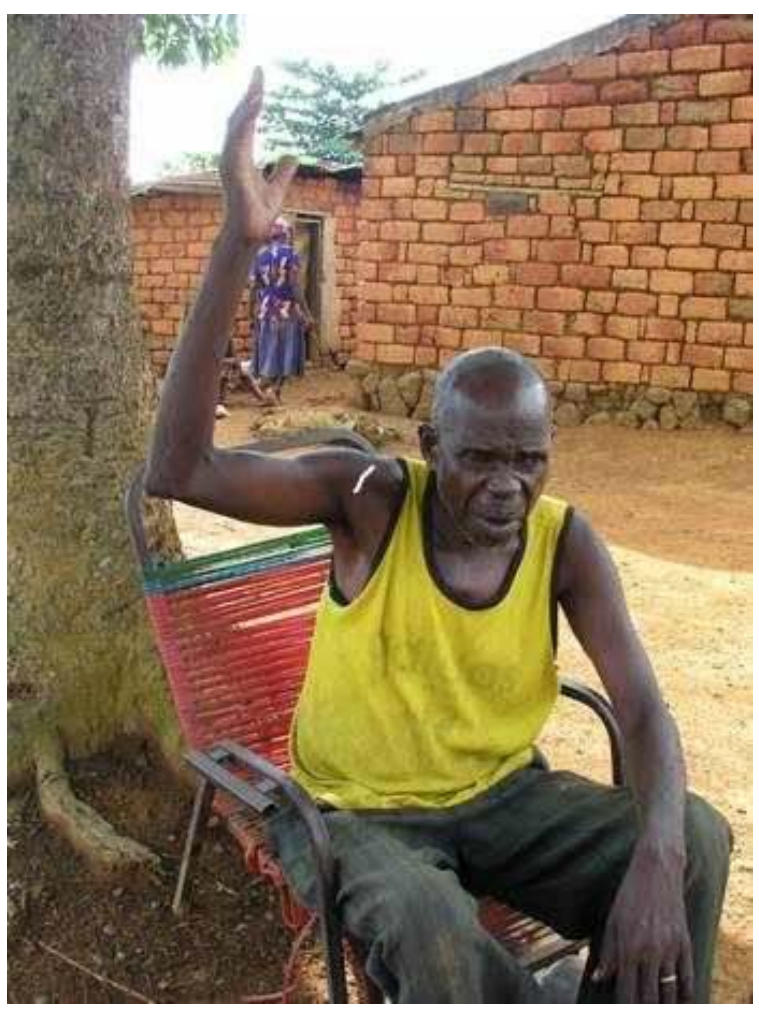

Photo Barbaro Martinez-Ruiz, 2003

The lower portion of the both figures depicts bent legs in the pose wienga. Wienga, as translated by Thompson, means "to melt the body in the music"12. It is known today in Mbanza Kongo as Kina or Kina Kuluka and means to dance or "the first position assumed by the body to begin to dance"13. This meaning persists in the diaspora as shown in Figures 4 . Finally, the bottom part of plate 2 pictures the two legs becoming rivers. In Kongo belief, river is the symbol of Simbi spirit, as a variation of the power of Simbi. ${ }^{14}$ 
Fig. 2. Juan Usera teaching the gesture Kina or Wienga as part of the Bomba and Plena folk dance at the Taller Boricua, Spanish Harlem, New York City, 1999.

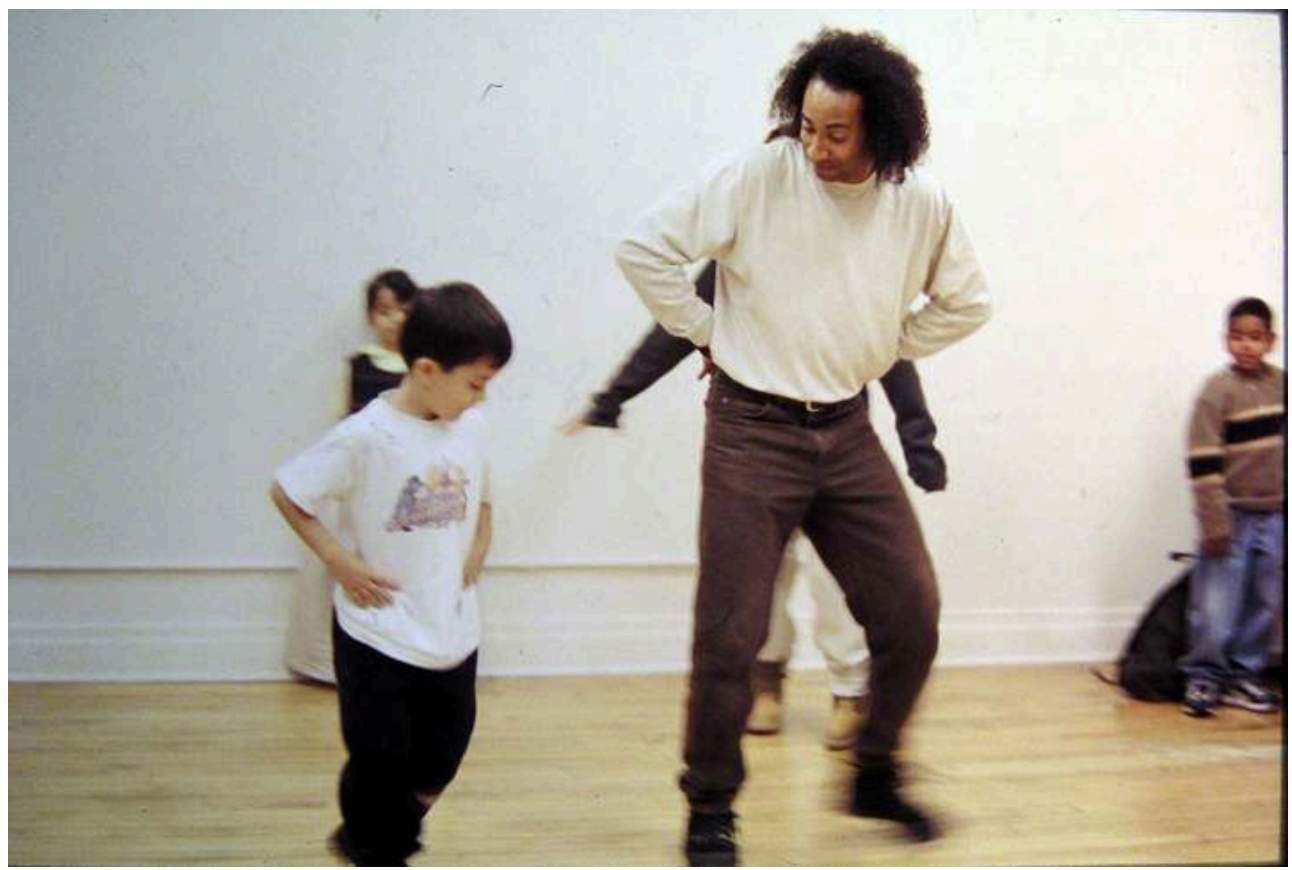

Photo Barbaro Martinez-Ruiz, 1999

What is interesting about plate 2 is the way in which the overlapping of abstractions results in a complex, but uninterrupted narrative. From its top to its base, reading the combination of all of its parts, we can interpret the cross-crowned head as an emblem of rising power or a spiritual journey, the arms as indicating power (lèndo) and signaling a flow of energy (ngolo) between the two worlds, the legs as referring to the ancestors that will come to offer protection during the journey and illustrate, through the coursing of a river, the manifestation of Simbi's power. Another example from Luvo is plate 3 depicting a body in the pose recognizable as Funguma. The position of the arms, open along the shoulder making an angle of thirty degree ending at shoulder level, means "to be confirmed in front the spirits ${ }^{15}$.

Plate 3 Luvo rupestrian painting. Adapted from Paul Raymaekers and Hendrik van Moorsel, 1962.

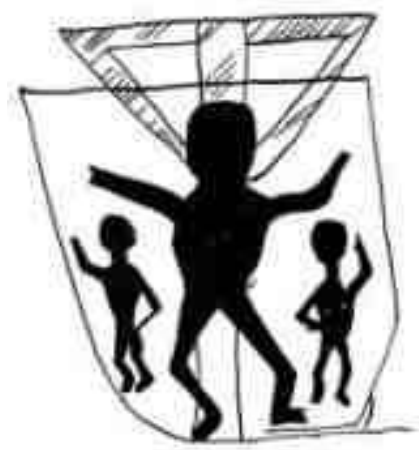

This pose is used in a ceremony to engage the ancestor that lives inside the munanso nzo (room of the spirit). During the ceremony, the priest stands in the doorway between 
the Munanso Nzo and another room where practitioners are gathered. With his back to the Munanso nzo, he pledges that the spirits are coming from behind to become one with him. Another name for this pose is Ngolo which translates as purification. Notably, in the Luvo depiction the figure's right arm is not shown in the same position as the left. If the two sides were balanced on the same level, that would direct it to another pose, named by Thompson Yamba. ${ }^{16}$ Yamba is a position with hands outstretched and fingers open, the palms facing outward along the vertical axis, that means "bring me peace." ${ }^{17}$ Among the Bundu dia Kongo and Mpeve a Nlongo churches in Angola this pose is known as Nuisa ${ }^{18}$ or Ziubuka Moko ${ }^{19}$ and also means peace or calm. Among the royal and traditional family members, it is known as Yamba and means rejoicing.

Another variation of the Funguma pose raises the hands higher, to finish just above the top of the head. This is called Nuvuanda or Nvuanda and means, "welcome to ancestors and please have a seat" ${ }^{20}$ When used in the religious performances of the Black People's Church in Africa (INAF) and Bundu dia Kongo (BDK), this gesture means "to open" ${ }^{21}$ and implies the willingness of the person that is communicating with the ancestors to receive them. It is made simultaneously with the recitation of the prayer "Nzambi ya ninkoko zia bianzi" that means "To say four prayers in the four cardinal points" and used to call the spirits from the four corners of the circle. Finally, this gesture refers to the first kind of Simbi spirit that has to be invoked through gesture, prayer and music. ${ }^{22}$

In this same example we can see that the Luvo figure is standing against a vertical center line that is crowned with an inverted triangle. The vertical line in this case is marking the sense of descent of the spirit form heaven to earth or from the ancestral world to the world of living. The inverted triangle emphasizes the sense of this descent from the sky towards the earth. Among practitioners of the church Bundu Dia Kongo, ${ }^{23}$ the Prophetic Church Mpeve a Nlongo, ${ }^{24}$ and the Botanical House of the Holy Spirit ${ }^{25}$ the triangle design is the sign of dead and indicates the way to meet the ancestors at the graveyard.

The outstretched arms form a gesture named Yangalala, mean ecstasy or happiness.

Plate 4 Luvo rupestrian painting. Adapted from Paul Raymaekers and Hendrik van Moorsel, 1962.

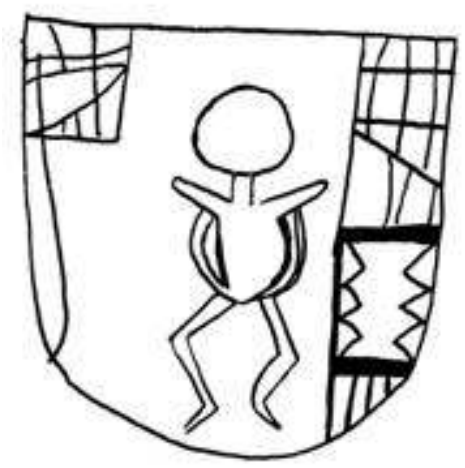

This gesture has been extensively studied by Thompson in his books The Four Moments of The Sun and The Kongo Gesture. In its contemporary form in Luanda and around Mbanza Kongo, Yangalala continues to mean ecstasy or happiness, but is called Kiese by 
Ntino Nzaku Nevunda or Yovo Kiese by Simao Kwanzambi Mundele. A further interesting detail depicted in plate 4 is that the figure seems to be coming out of a hole or crossing through a hoop. This represents the idea of coming back after being gone, the idea of a rennaissance. It is a second sun that illustrates the sign of the cicle of life and death that is ingrained in Kongo philosohy through the Dikenga cosmogram which implies that coming back means birth, or when human first appeared on earth. ${ }^{26}$ In addition to the circle that constitutes the head there are two curves that indicate "the arch in the sky." 27 This arch means that one is protected by the banganga (priests) in the community, that one's family is protected, and that the arch may be used for invovcation and to request assistance. The arch is also a symbol of the Luyalungulu (Space). ${ }^{28}$ Additionally, the use of the two arches makes it appear that three concentric circles have been drawn. The circle has a basic meaning in Kongo culture of beginning, creation, and protection. This is recorded in a mambo by Bunseki FuKiau that states, "three circles control your life, you will be safe in the three circles." 29 The use of three in this example also means love, truth and justice and is the optimal graphic symbol of Nzambi Mpungu (God).

Plates 5, 6. Luvo rupestrian painting. Adapted from Paul Raymaekers and Hendrik van Moorsel, 1962.
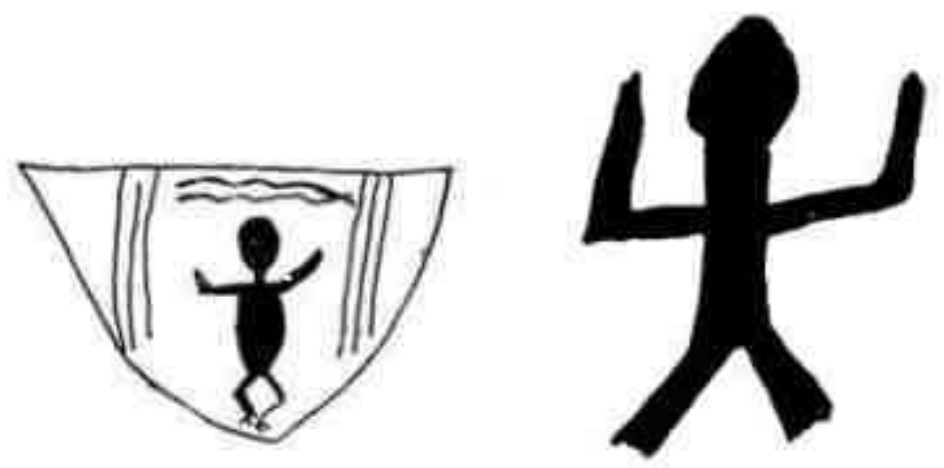

Plates 5 and 6 both illustrate the same upper body gesture, Fukama that means "spiritual cleasing, and resolution of problems" 30 in Mpeve a Nlongo and Bundu dia Kongo churches. Fukama can also be used to describe a position in which the arms are as portrayed here, but the individual is kneeling down. In that case, Fukama means "kneeling as sign of respect." ${ }^{11}$ An early depicption of this gesture is represented in Giovani Antonio da Montecuccolo Cavazzi's book, Istorica descrizione de' tre regni Congo: Matamba ed Angola, first vol. ${ }^{32} \mathrm{As}$ decribed by Cavazzi, Figure X illustrates a dance or public performance known as Maquina (machine) and typically done in the presence of the King or Prince to honor the leader..$^{33}$ The figure in the center of the image is making a clear example of the Fukama gesture. 
Fig. 3. From Giovani Antonio da Montecuccolo Cavazzi in Istorica descrizione de' tre regni Congo: Matamba ed Angola, 1687.

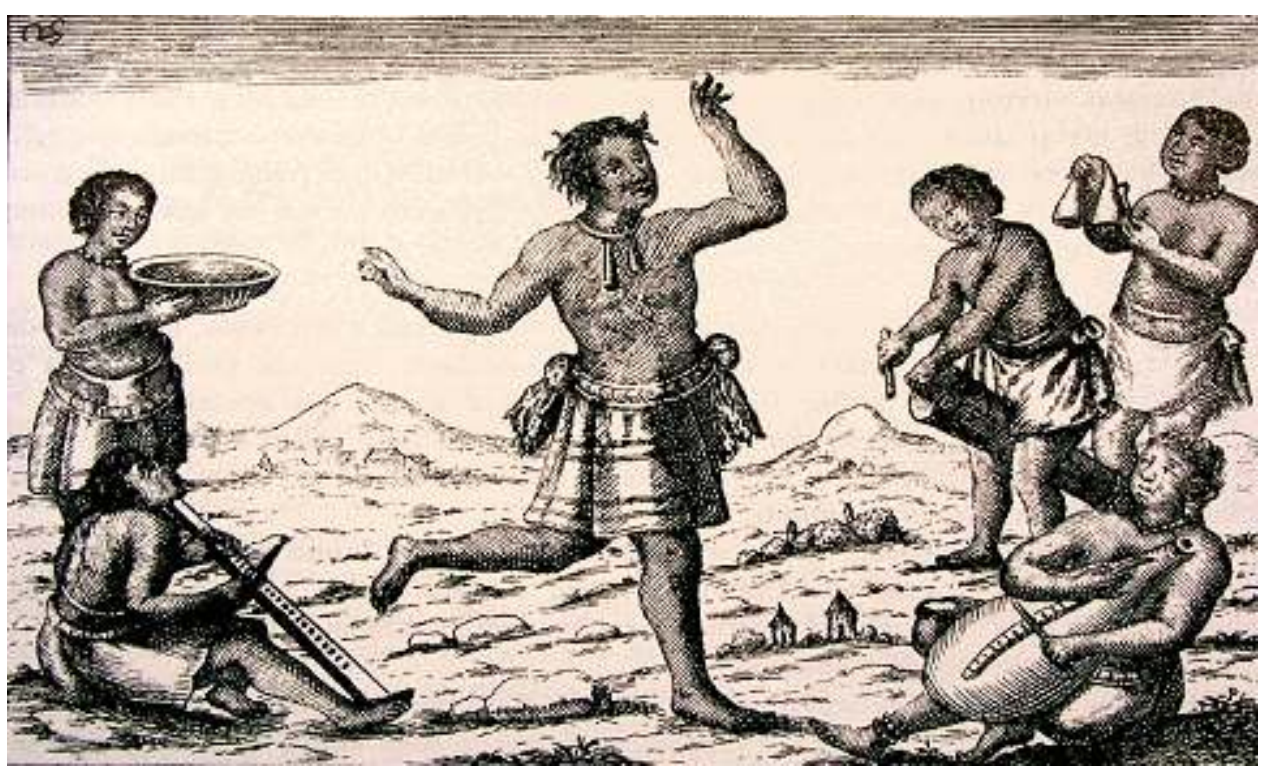

Photo Barbaro Martinez-Ruiz, 2004

This gesture continues to be widely used in and beyond Angola over three hundred years since its documentation by Cavazzi.

The primary difference between the two Luvo depictions of Fukama is that plate 5 is shown inside a space that resembles a curved inverted triangle. This frames the figure and clearly marks the horizontal line on the top of the drawing. This top line functions as Kalunga and is reinforced by the undulating lines between it and the figure which emphasize the water, a further allusion to Kalunga's strength. If we look carefully, the frame seems like the bottom part of the cosmogram dikenga, which means the spiritual world, the moment of earth's conception. Reading through this sign, one begins with the notion of Kalunga, an epithet of Nzambi Mpungu (God) and proceeds to identify the figure as "the one-who is complete, by himself the all-in-all," ${ }^{44}$ The sign is also an emblem of the presence of the complete power that created life and the universe and made things happen.

Plates 7-8 show a gesture that has had tremendous influence in the diaspora. In Mbanza Kongo, the same gesture is used in the Bundu dia Kongo, Mpeve a Nlongo and Botanical House of Mbanza Kongo churches under the name Lusaso Seka that means to "call for attention, or making connection with God." ${ }^{35}$ Nzaku Nevunda calls this gesture Fundisua kua Ludi, which means "Oath of innocence in front of the town." 36 
Plates 7 and 8. Luvo rupestrian painting. Adapted from Paul Raymaekers and Hendrik van Moorsel, 1962.
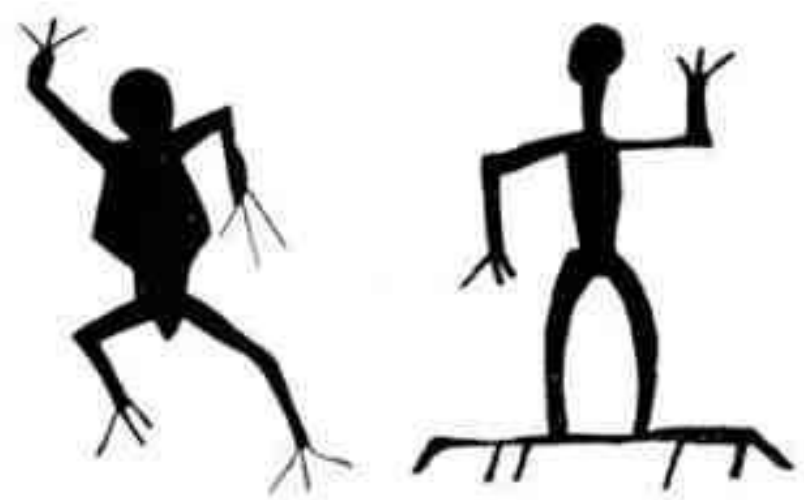

One apparent contradiction in these two depictions of Lusaso Seka is that it is depicted with the opposite hand raised. Current understanding of this gesture among the Bakongo and neighboring people holds that must be done with the right hand held up. The right hand is the hand of firmness, whereas the left hand (lumoso) "is a symbol of the forbidden, and of disrespect." ${ }^{37}$ From right to left is the way to read a cosmogram, it is the way a deceased person talks, it is the direction in which Simbi blows to call attention.

In Thompson's book The Four Moments of The Sun, there is an extensive explanation of how this gesture is used in the niombo cloth mannequin tradition of the Bembe and Yombe peoples in Democratic Republic of Congo and Cabinda, Angola. For Thompson niombo was more than a mannequin, but rather a type of N'kisi. ${ }^{38}$ Crucial to the niombo aesthetic, Thompson argues, is the meaning of each figure's body language. He emphasizes the position of the hands, the right hand up, left hand down, and explains that this form means communication with the other world. Giving more details, Thompson writes "It maps the boundary to be crossed; it identifies the cord connecting life to death; it is the crossroads pose." ${ }^{39}$

31 Unlike in plate 8, where the two legs are at the same level, in plate 7, the left leg appears to be stepping forward when compared to the right leg, This means that it is a sign of expansion or communication of the soul, facilitating exchange and continuity between one's self and the ancestor's spirituality. ${ }^{40}$ Similarly, the left foot is used to begin the mambo and to initiate communication with bandoki (evil spirits) as necessary to defeat and prosecute them, whereas the right foot is the sign of môyo (life), and thus a symbol of the soul. ${ }^{41}$

The final examples from Luvo are the plate 10, and multiple variations of the same pose in plate 11. These represent the gesture known as Mavimbi among people in Mbanza Kongo. ${ }^{42}$ For Nzaku Nevunda, Mavimbi means "to salute, give a greeting," ${ }_{43}$ while the gesture is explained by the religious groups as a "sign of joy, pleasure and delight." 44 The same gesture is also conceptualized by Simão Kwanzambi Mundele as Zitu which means an "emotional load." ${ }^{45}$ 

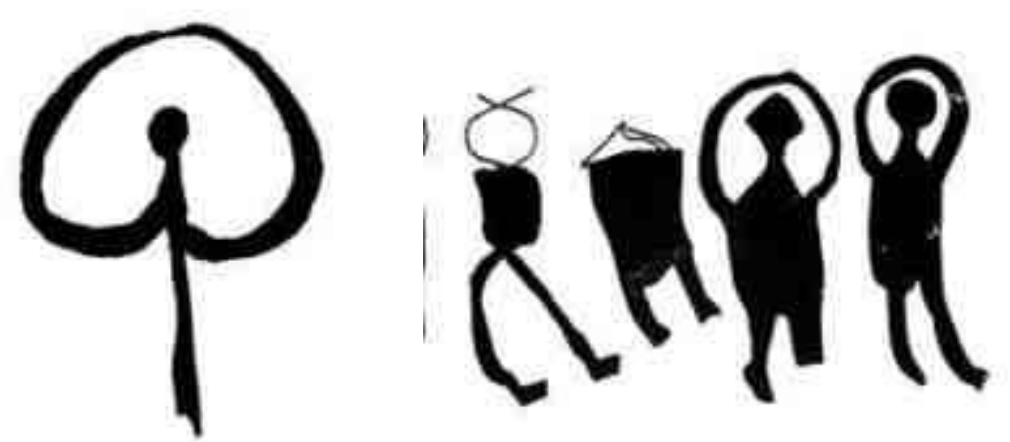
figure becoming a dot inside the circle formed by the arms meeting above. This abstraction and simplification of the pose clearly alludes to the meanings of the shape itself. A circle with a dot in the center is explained by Bunseki FuKiau to reflect "the pressure from the external world on the individual. The dot is a symbol of self-control, and the circle is symbol of inner power control. The dialectic balance of inside and outside keep harmony." ${ }^{46}$ In addition, FuKiau adds that the sign could be read to imply that one needs to be aware or alert. The combination of the circle with the body shows further complexity as the circle on top of the vertical line can be read as a single sequence. Bunseki FuKiau explains that this combination means "We are talking about verticality and cosmic power. When we are dreaming, something happens in the community; dreaming from the cosmos or cosmic dreams." ${ }^{47}$ The vertical line also illustrates Mukula, which, , means "the axis of time, or in the direction of the ancestors." ${ }^{48}$

beyond Luvo. One of the most common gestures seen in regional rupestrian art is an upright figure with the hands on the hips. This pose has been documented by Carlos Ervedosa in Delembira from around the XVII century, in Quinhendo rock painting, Cambambi, Pedra do Feitiço from around the XVII and XVIII centuries, and Galamba from over 4,100 years ago.

Robert Farris Thompson, in The Four Moments of the Sun, calls this gesture pakalala and describes it as "stand[ing] with hands on hips, a position which symbolizes brave readiness to take on any lawsuit, no matter how severe." ${ }^{49}$ In Mbanza Kongo, the same gesture is called Lulendo by Simao Kwanzambi Mundele and used to signify that the person is ready to respond to any attack or personal challenge from his community. Similarly, Francisco Lusolo referred to this gesture as Nzambi ntoto, but also explained that it is a stance indicating readiness to respond, balance and meditation. This gesture is also widely seen in the diaspora where it is exclusively used to signify readiness..$^{50}$ There is another example of a gesture found in the rupestrian painting at Delambira. The gesture, Ndingama, as explained by Ntino Nzaku Nevunda and Mayifwila Rafael Rivals, means to stop, suspend a performance, or to open spiritually. There is clear continuity between the gestures depicted in cave painting dating back thousands of years and the use of the body for communication in present day Angola

Les actes de colloques du musée du quai Branly Jacques Chirac, 2 | 2009 
and parts of the Caribbean. In addition to the archeological evidence, visual documentation of early encounters between Europeans and the Bakongo of Central Africa demonstrates the frequent and public use of gestural communication in the XVII century. Most informative in this sense are the illustrations in Giovani Antonio da Montecuccolo Cavazzi's book, Istorica descrizione de' tre regni Congo: Matamba ed Angola, first vol. Cavazzi's skill in capturing Bakongo daily life through his illustrations accurately noted, contextualized, and preserved a number of important gestures. One such illustration is cited above in the discussion of the gesture Fukuma. Cavazzi's illustration in figure 20 by his account shows local people welcoming the Portuguese's capuchin monks to the kingdom of Soyo around 1645. According to Cavazzi, the monks were performing baptism of children and adults in order to free then from evil..$^{51}$ In the center of the illustration, a local person is pictured making a gesture of reverence to a European capuchin monk..$^{52}$ The gesture, arms crossed on the chest, is called Dielebetela, Luyindilulu, and Nkutakese moko by Ntino Nzaku Nevunda, Simão Kwanzambi Mundele, and Francisco Lusolo respectively.

The sources in Mbanza Kongo all stated that the gesture means that communication among two parties is real, that it is happening. Alternatively, the same gesture can mean meditation and imply that the person making the gesture is concentrated on himself. The final meaning described by these offered by Nevunda, Mundele, and Lusolo, and the one that matches Cavazzi's description, is a salutation, greeting or welcome. Robert Farris Thompson, in The Four Moments of the Sun, identified this gesture as Tuluwa lwa Luumbu and also stated that the arms crossed upon the chest were a salutation. ${ }^{53}$ Thompson described it as a core gesture used in the folk dance named Rumba Yambu and still performed in Cuba today. ${ }^{54}$

The other important gesture seen in Cavazzi's illustration are the figures on the left and right sides of the frame, clasping their hands together. This gesture is known as Lusito by Ntino Nzaku Nevunda and Nzambi by Francisco Lusolo. It means to honor God.

Fig. 5. Ntino Nzaku Nevunda, Mbanza Kongo, Angola, 2003.

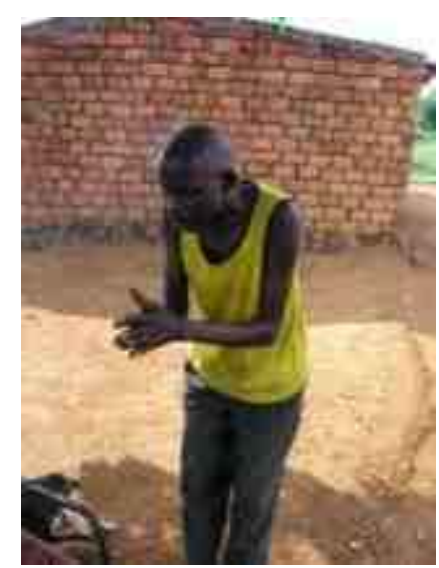

Photos Barbaro Martinez-Ruiz

An illustration from Cavazzi shows the king of Mani Kongo Alvaro VI receiving the Capuchin order from Lisbon ${ }^{55}$. The image depicts a local mukongo person in the lower right of the frame, making a gesture with his right hand over his chest and left hand pointing towards the ground. This gesture is known in Mbanza Kongo as either Vumuka, ${ }^{56}$ meaning affirmation and agreement, or Kintulu, meaning a constant remainder of a 
beloved family member. ${ }^{57}$ It is also interesting to note that in Cavazzi's image, the Europeans are depicted making a gesture in the same fashion, but using their left hand to cross the chest instead. Although unclear, it is likely that the Europeans were attempting to mirror a gesture they observed. However, as noted above, among the Bakongo the left hand is rarely used as it signifies malice or evil thought about someone or something. ${ }^{58}$

41 The illustration from Cavazzi in figure 28 depicts a person in the center making the gesture Lomba or Lomba kia Mzambi by holding out his hands while kneeling down. This position, according to Ntinu Nzaku Nevunda and Francisco Lusolo, is used to call God or to demand answers from the ancestors. Cavazzi provides a similar explanation, writing that the person is invoking the spirit of the dead. ${ }^{59}$ This position and a number of similar gestures continue to be important among the Bakongo today. Lomba is portrayed in figure 6 , whereas the position with the hands raised to the height of the ears with hands wide open from the body is called as Nevuanda. As described earlier, this variation means to welcome the ancestors or open the spiritual connection between humans and ancestors..$^{60}$ The final variation of this gesture is called Funguma ${ }^{61}$ or Ngola ${ }^{62}$ and means confirmation in front of the spirits and purification.

The final informative illustration from Cavazzi's work shows Queen Jinga of Matamba Kingdom around 1657 in the center of her traditional compound. ${ }^{63}$ The queen is depicted in the position Funda Nkata, a very common pose among the noble class and religious authorities that indicates dignity or authority. Individuals who go to visit a high ranking noble must make this gesture as a sign of respect. Other related meanings of Funda Nkata are protection, perfection, meditation in the circle of the ancestors, and the beginning of creation. ${ }^{64}$

Fig. 6. Giovanni Antonio da Montecuccolo Cavazzi in Istorica descrizione de' tre regni Congo: Matamba ed Angola, 1687.

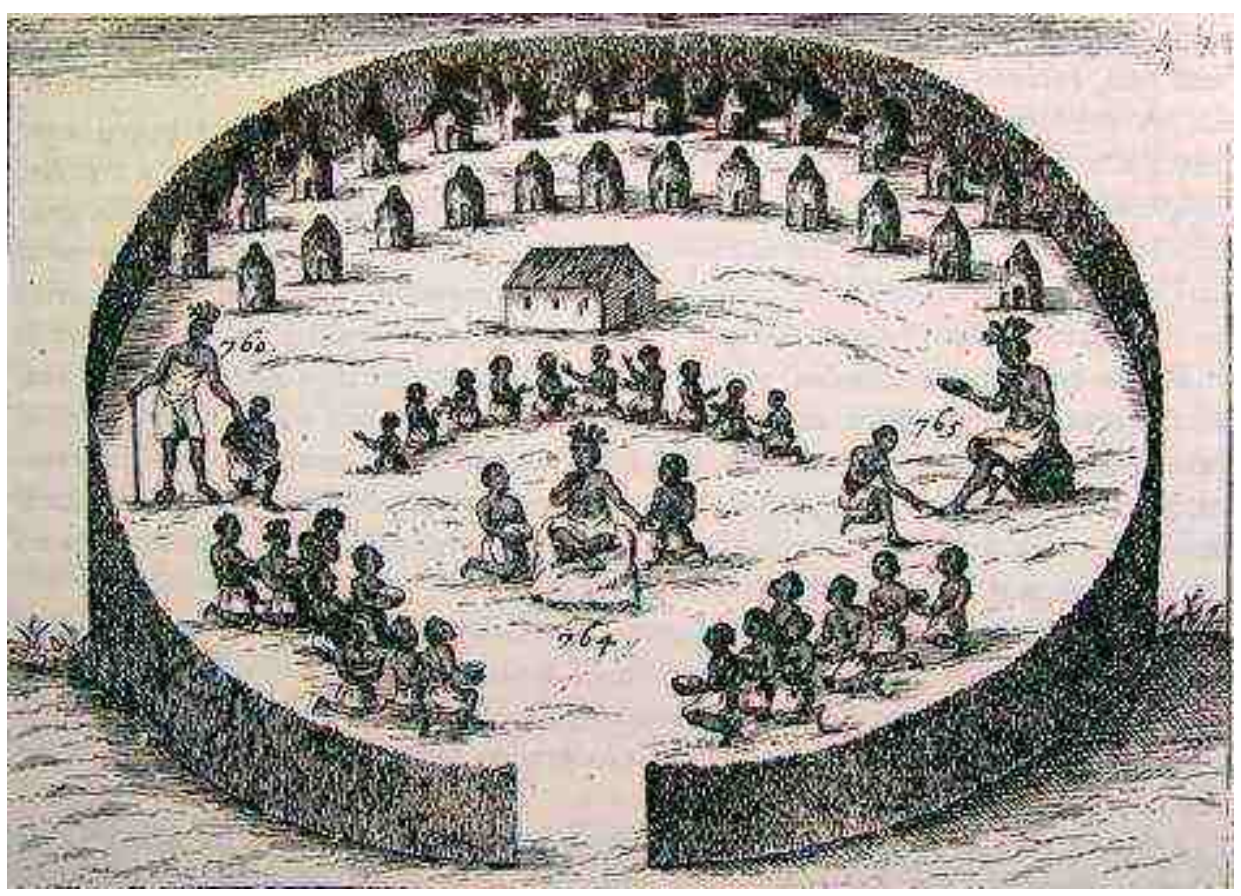

Photo Barbaro Martinez-Ruiz, 2004 

Kongo in the year 2003 in the Funda Nkata pose. The picture was taken during a rehearsal of the Mpidi, a religious performance traditionally used to mummify and elevate the King's spirit. ${ }^{65}$

Fig. 7. A member of the Kongo traditional authority named the "Traditional Circle" during a traditional performance, Mbanza Kongo, Angola, 2003.

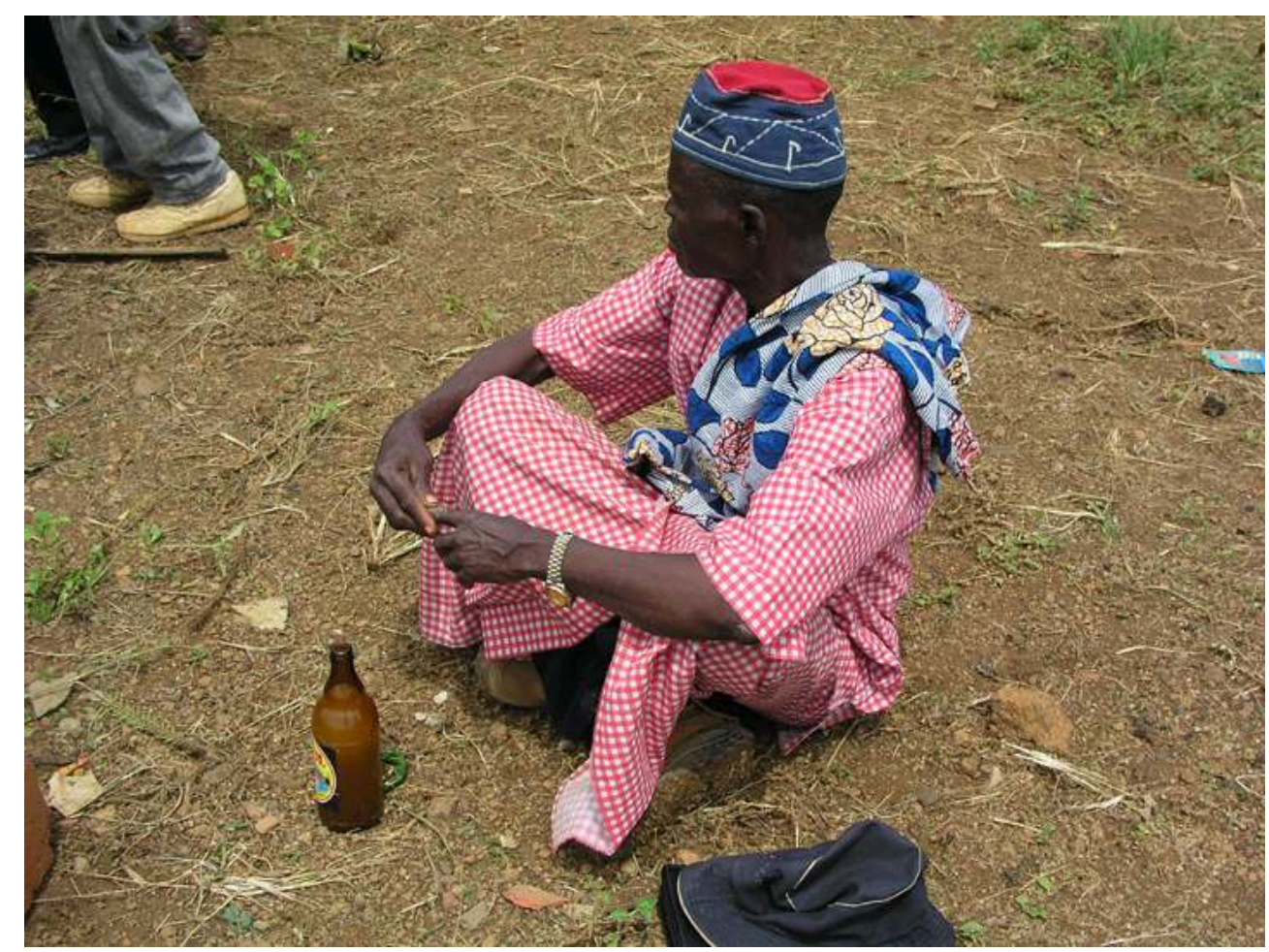

Photo Barbaro Martinez-Ruiz

The gestures depicted by Cavazzi and seen in contemporary usage have also been depicted for centuries by the Bakongo themselves through their artwork. The following examples highlight gestures commonly portrayed in Nkisi Nkondi figures and other types of sculpture. In Bakongo body communication, there are several variations of crossing the arms over the chest. One such pose involves each hand grabbing the opposite shoulder. This is known as Moko ya Nkenda according to Ntino Nzaku Nevunda and as Giangula according to Simão Kwanzambi Mundele, meaning sorrow and lamentation respectively. This gesture is often confused with the gestures Dielembeta or Tuluwa lwa Luumbu which similarly involve crossing the arms across the upper body but can be differentiated by the level at which the hands come to rest. Moko ya Nkenda is commonly depicted in the context of mourning and funearl art, for example a stone sculpture from the XV or XVI century found at the Mantadi cemetary in the border region between the Democratic Republic of Congo and Angola.

Thompson's description of the piece names the gesture Lumbu or Tuluwa lwa Luumbu and provides a more complex explanation of its meaning. He writes that it has to do with placing yourself behind a walled enclosure, symbolizing: (1) building a pyschological barrier between the person and the chill... (2) a declaration of sadness, of isolation from normal living, by grief or melancholy; and (3) symbolic termination, by 
visual barrier, of feelings of discrepancy remaning between the dead leader honored by this stone and certain of the lviing community ${ }^{66}$.

A second variation of the crossed arms lowers the position of the hands slightly so that they rest just below the shoulders. Ntino Mnzaku Nevunda calls this position Masaka saka and describes it indicating that something is enough. ${ }^{67}$ Thompson cites a similar meaning for this pose and describes its contemporary usage among African descendents in the Diaspora in The Four Moments of the Sun. Thompson states that the crossed arms "symbolize self-encirclement in silence" and are used to signal that one has no more to say, that a conversation is over. ${ }^{68}$ As noted above in the context of a Cavazzi illustration, Thompson also refers to the gesture's usage as a salutation. The final variation is when the arms are crossed upon the belly making a horizontal line by grabbing onto the opposite forearm with each hand. When done inside a religious setting, this gesture is understood to show respect for the elders or to engage the ancestors. It has been called Luzitu by Simão Kwanzambi Mundele and Lomba fuiri by Francisco Lusolo and Mayifwila Rafael Rivals. Beyond its religious meaning, this gesture is used colloquially to allude to the blessings of the ancestors and impart good wishes or wish an acquaintance good luck in passing. ${ }^{69}$

Another important pose seen frequently in Bakongo daily life and in their art is formed by kneeling down and placing ones hands on the knees. This position, known as Fukama, ye mooko va bunda according to Thompson, is "an ancient pose of assuagement, of asking for forgiveness." 70

Variations of this pose are generally achieved through other positions or activities of the hands. For example, Figure 47 shows Alfonso Seke in the Fukama position, which he also refers to as Lukofi, but he is clapping his hands. This distinction occurs in the context of high-level religious gatherings. The clapping, generally done three times, shows reverence for other group members or indicates that the person clapping has the right to speak. Another example is seen in figure 48, where a member of the Mpeve a Nlongo Church in Mbanza Kongo makes a similar pose named Tuntu where the hands are clasped behind the back. This position indicates that the individual has done something wrong and acknowledges that he or she will be judged by the priest. In addition to asking for forgiveness, the pose expresses one's sadness and inner suffering.

The gesture shown below implies either deep thought or worry and concern. With their hands clasped behind the head, it is called Ndingu by Ntino Nzaku Nevunda and Simbidi unto by Francisco Lusolo. Lusolo goes on to explain that the pose could have three different meanings according to the position of the head. If the head is tilted upwards, facing the sky, the gesture is called Mambu Ndingu and the problem referred to is spiritual or related to God. If the head is looking outward, facing the horizon, it is named Yindula and refers to a problem in the present. Finally, if the head faces the ground, the gesture is called Luyindulu and means one is thinking about death or a problem related to his or her life or family. 
Ntino Nzaku Nevunda, Mbanza Kongo, Angola, 2003.

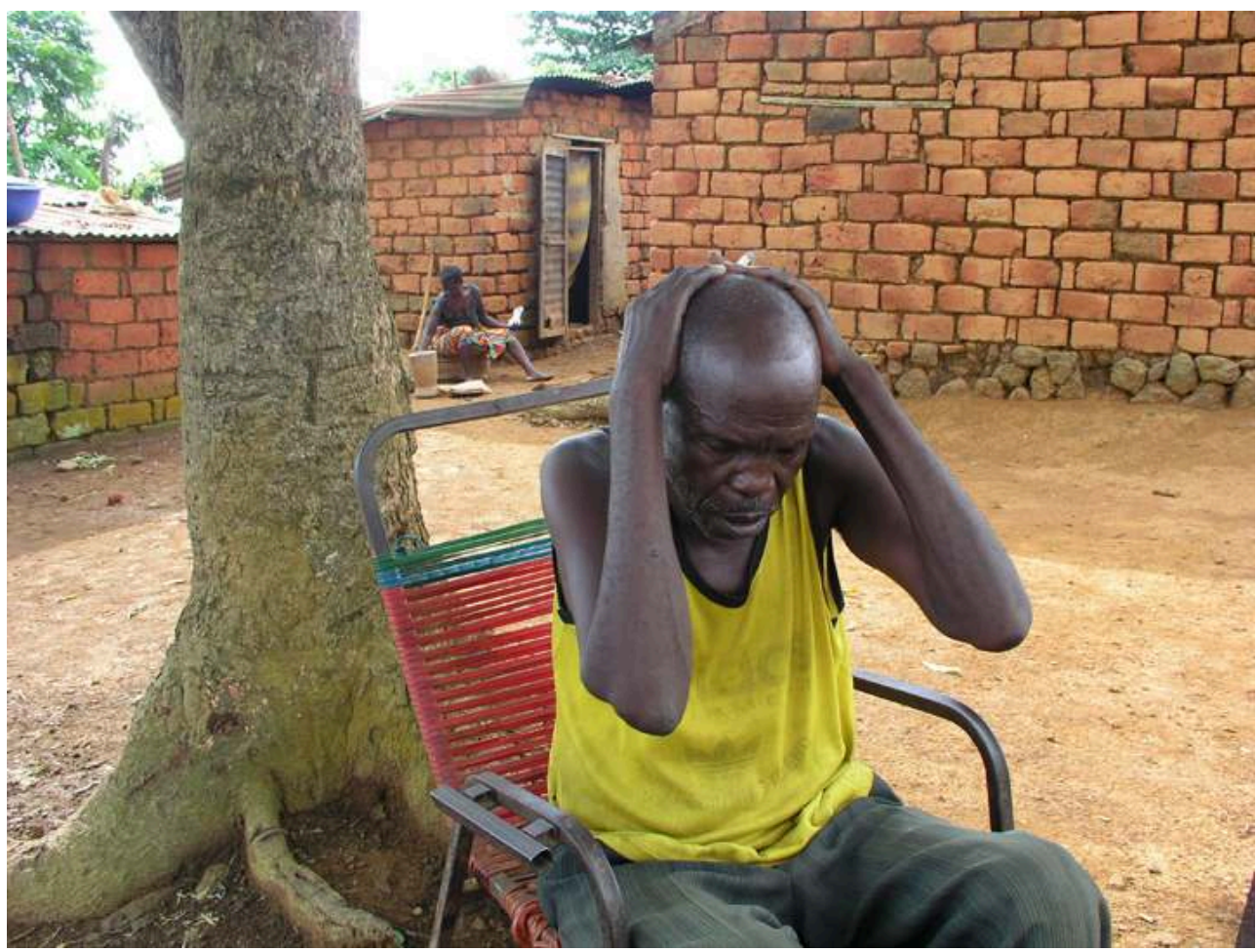

Photo Barbaro Martinez-Ruiz

Another gesture with similar, but more specifically defined meaning show contemporary usage and an early Mintadi sculpture from the XV or XVI centuries. Made by placing the left hand against the cheek and the right on the hip, this pose was explained by Ntino Nzaku Nevunda to mean one is looking for a solution or response to a problem. ${ }^{71}$ Thompson similarly describes the position as one of thought and arresting evil in The Four Moments of the Sun. ${ }^{72}$ preceding examples were selected to demonstrate the range and depth of meaning attributed to physical signs. In shorthand form, the following table includes these and other common examples of body vocabulary and the meanings associated with them in Mbanza Kongo.

Mbanza Kongo Gesture Glossary

\begin{tabular}{|l|l|l|lr|}
\hline Gesture & Ntino Nzaku Nevunda & $\begin{array}{l}\text { Simao } \\
\text { Kwanzambi } \\
\text { Mundele }\end{array}$ & $\begin{array}{l}\text { Mayifwilar Rafael } \\
\text { Revals, Francisco } \\
\text { Lusolo, BDK Church }\end{array}$ \\
\hline
\end{tabular}




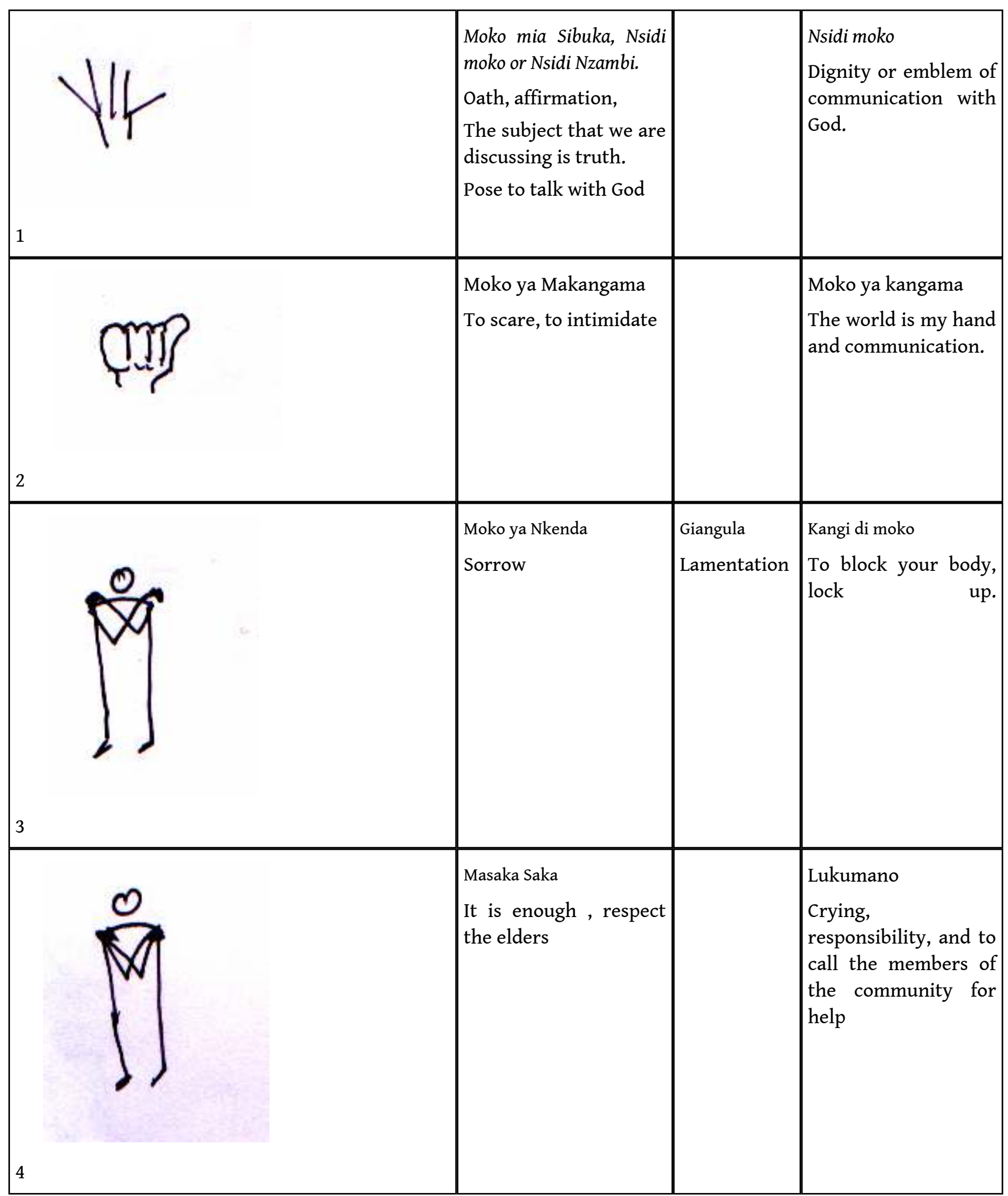




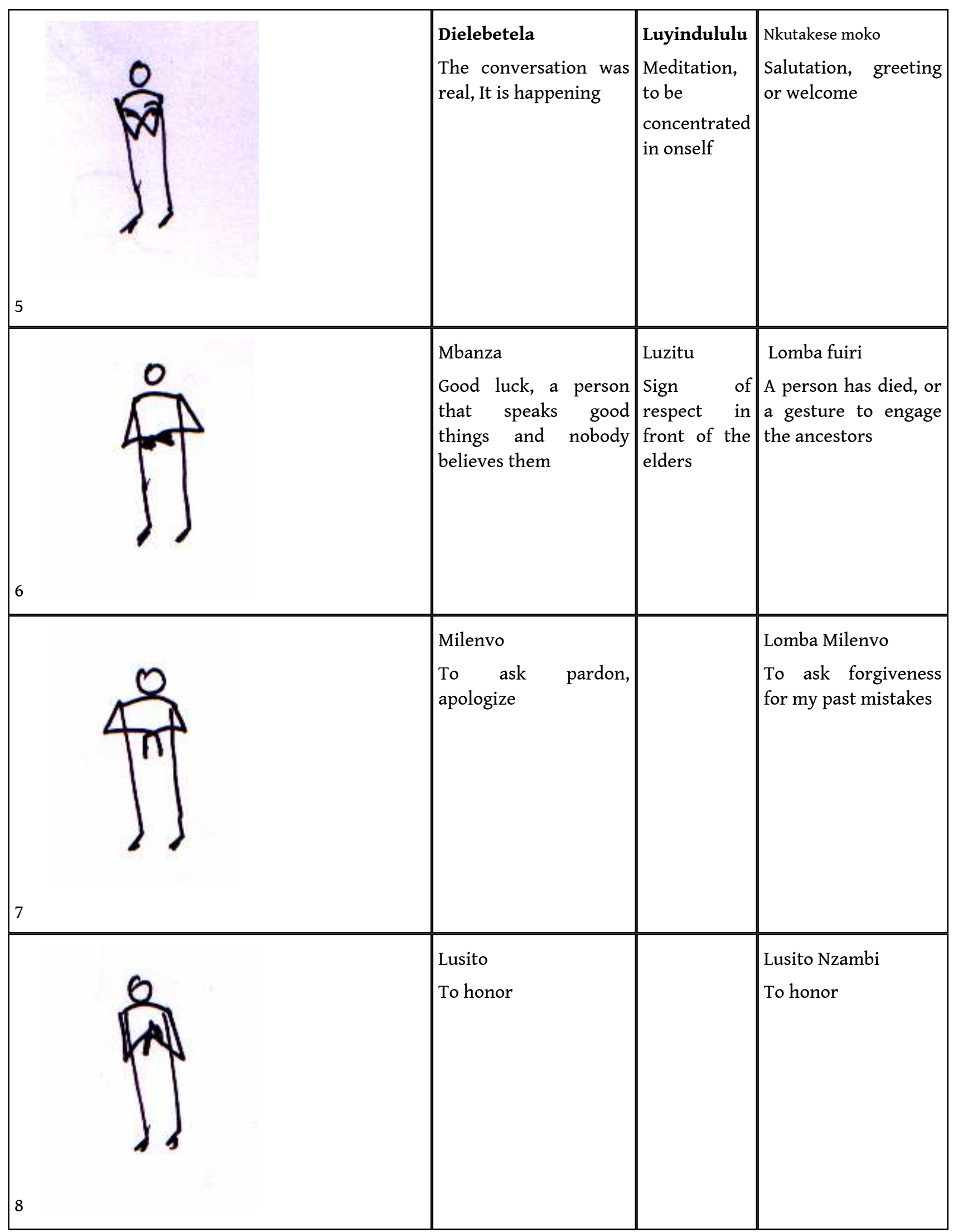




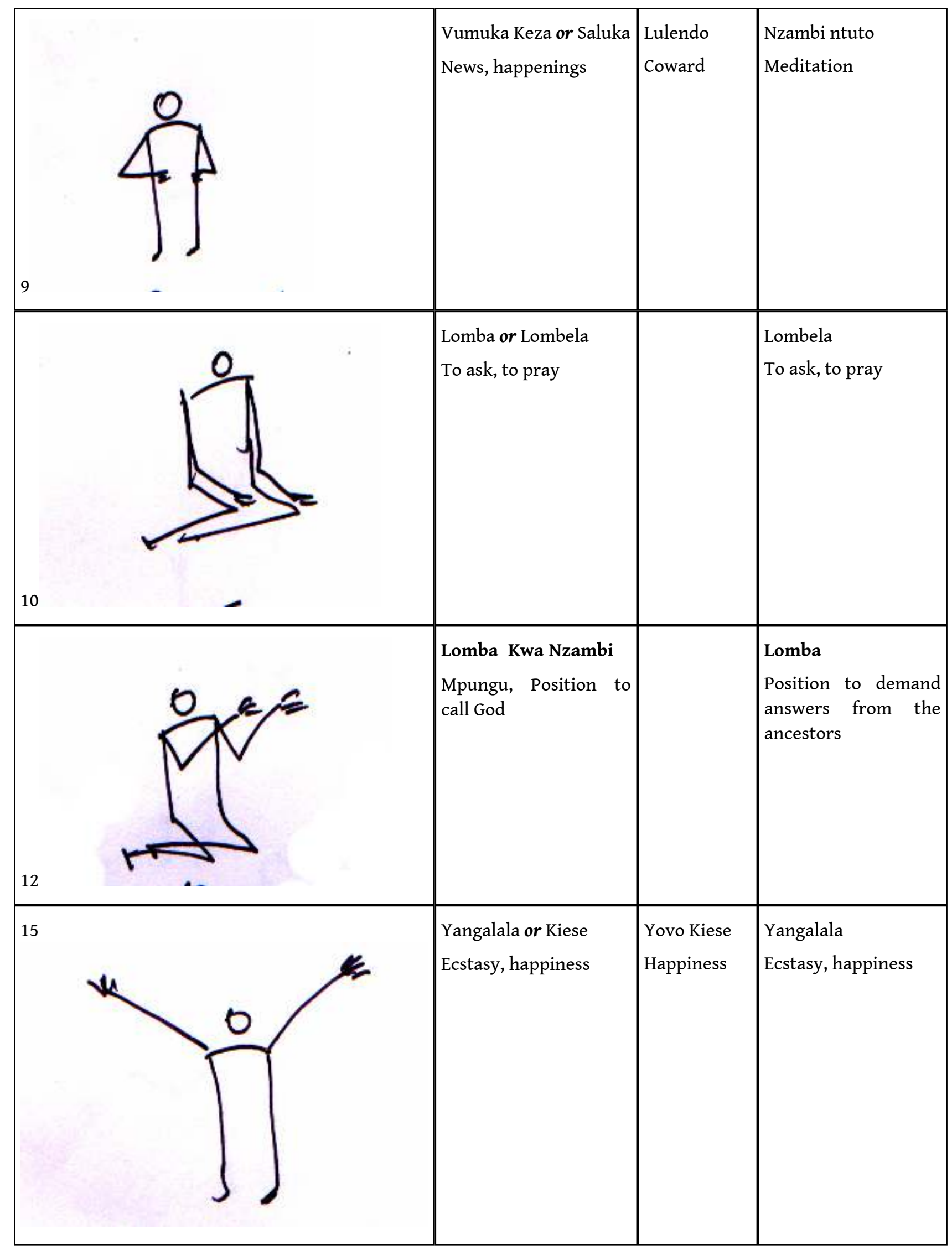




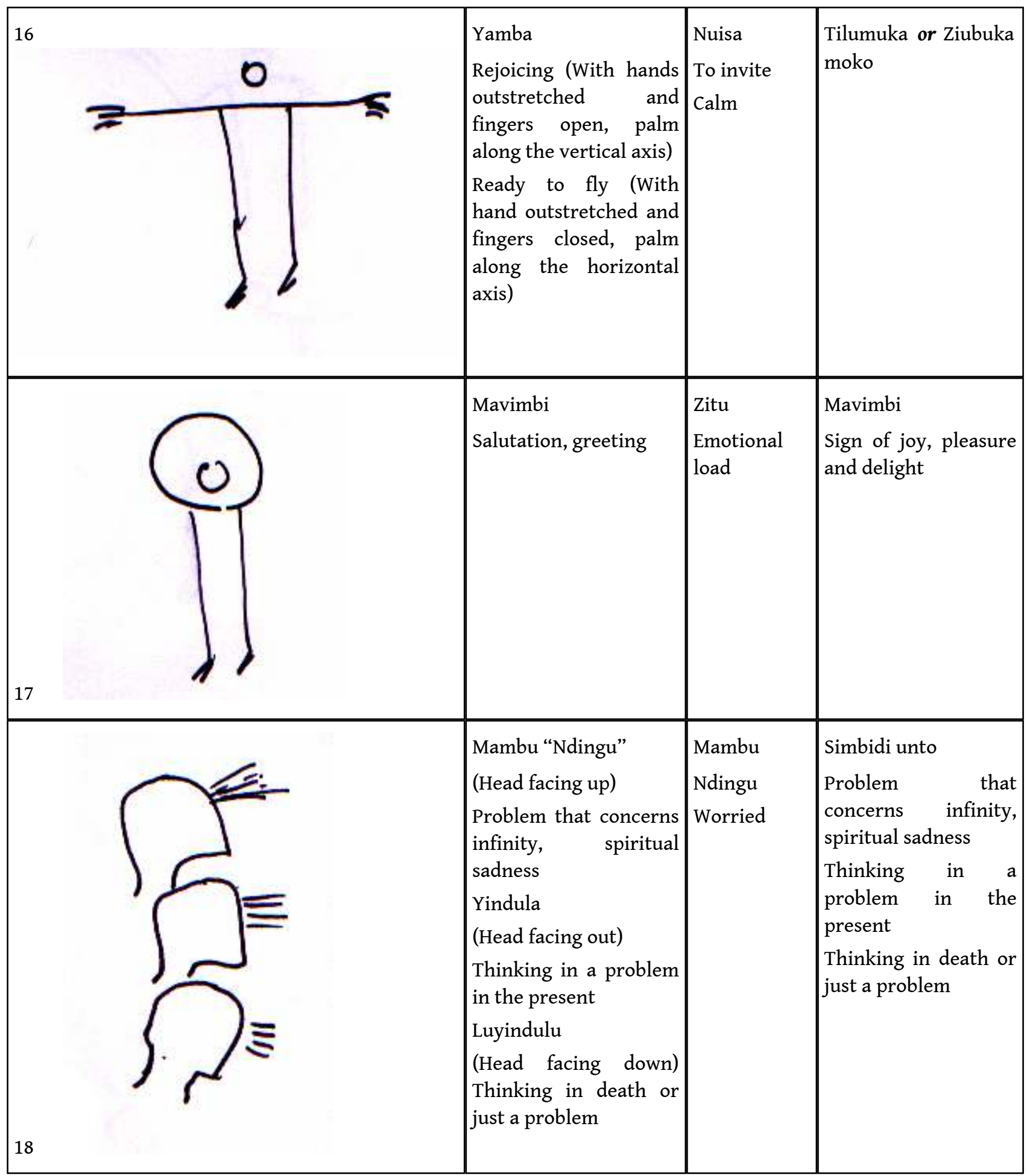




\begin{tabular}{|c|c|c|}
\hline 19 & $\begin{array}{l}\text { Fundisua kua Ludi } \\
\text { Oath of innocence in } \\
\text { front of the town }\end{array}$ & $\begin{array}{l}\text { Lusaso seka } \\
\text { Call for attention or } \\
\text { making connection } \\
\text { with God }\end{array}$ \\
\hline 20 & $\begin{array}{l}\text { Ndingama or Kala } \\
\text { Vovo } \\
\text { A stop, a temporary } \\
\text { suspension of the } \\
\text { performance }\end{array}$ & $\begin{array}{l}\text { Ndingama } \\
\text { A stop, a temporary } \\
\text { suspension of the } \\
\text { performance, an } \\
\text { interval } \\
\\
\\
\end{array}$ \\
\hline 21 & $\begin{array}{l}\text { Nfoko } \\
\text { The end of the } \\
\text { program or agenda }\end{array}$ & $\begin{array}{l}\text { Nfoko } \\
\text { The end of the } \\
\text { program or agenda }\end{array}$ \\
\hline 22 & $\begin{array}{l}\text { Telema } \\
\text { To stop }\end{array}$ & $\begin{array}{l}\text { Telema, Simbidila or } \\
\text { Nzambi ntuto } \\
\text { Communication with } \\
\text { a dead person and } \\
\text { honoring them }\end{array}$ \\
\hline
\end{tabular}




\begin{tabular}{|c|c|c|}
\hline 23 & $\begin{array}{l}\text { Funguma } \\
\text { Confirmation in front } \\
\text { of the spirits }\end{array}$ & $\begin{array}{l}\text { Ngola } \\
\text { Purification }\end{array}$ \\
\hline 24 & $\begin{array}{l}\text { Nuvuanda } \\
\text { Welcome to ancestors } \\
\text { "Please have a seat" }\end{array}$ & $\begin{array}{l}\text { Nuvuanda } \\
\text { To open }\end{array}$ \\
\hline 25 & $\begin{array}{l}\text { Fukama } \\
\text { Sign of respect }\end{array}$ & $\begin{array}{l}\text { Fukama } \\
\text { Spiritual cleansing, } \\
\text { and resolution of the } \\
\text { problem }\end{array}$ \\
\hline
\end{tabular}




\begin{tabular}{|c|c|c|}
\hline 26 & $\begin{array}{l}\text { Dingama } \\
\text { To stop }\end{array}$ & $\begin{array}{l}\text { Dingama } \\
\text { To open spiritually, } \\
\text { or to suspend the } \\
\text { performance }\end{array}$ \\
\hline \multirow{2}{*}{\multicolumn{3}{|c|}{$\begin{array}{l}\text { Kina } \\
\text { Ready to dance } \\
\text { To dance }\end{array}$}} \\
\hline & & \\
\hline & $\begin{array}{l}\text { Vumuka or Vumukina } \\
\text { Affirmation, sign of } \\
\text { agreement }\end{array}$ & $\begin{array}{l}\text { Kintulu } \\
\text { Sign of constant } \\
\text { reminder of a } \\
\text { beloved } \\
\text { member }\end{array}$ \\
\hline 28 & & \\
\hline
\end{tabular}




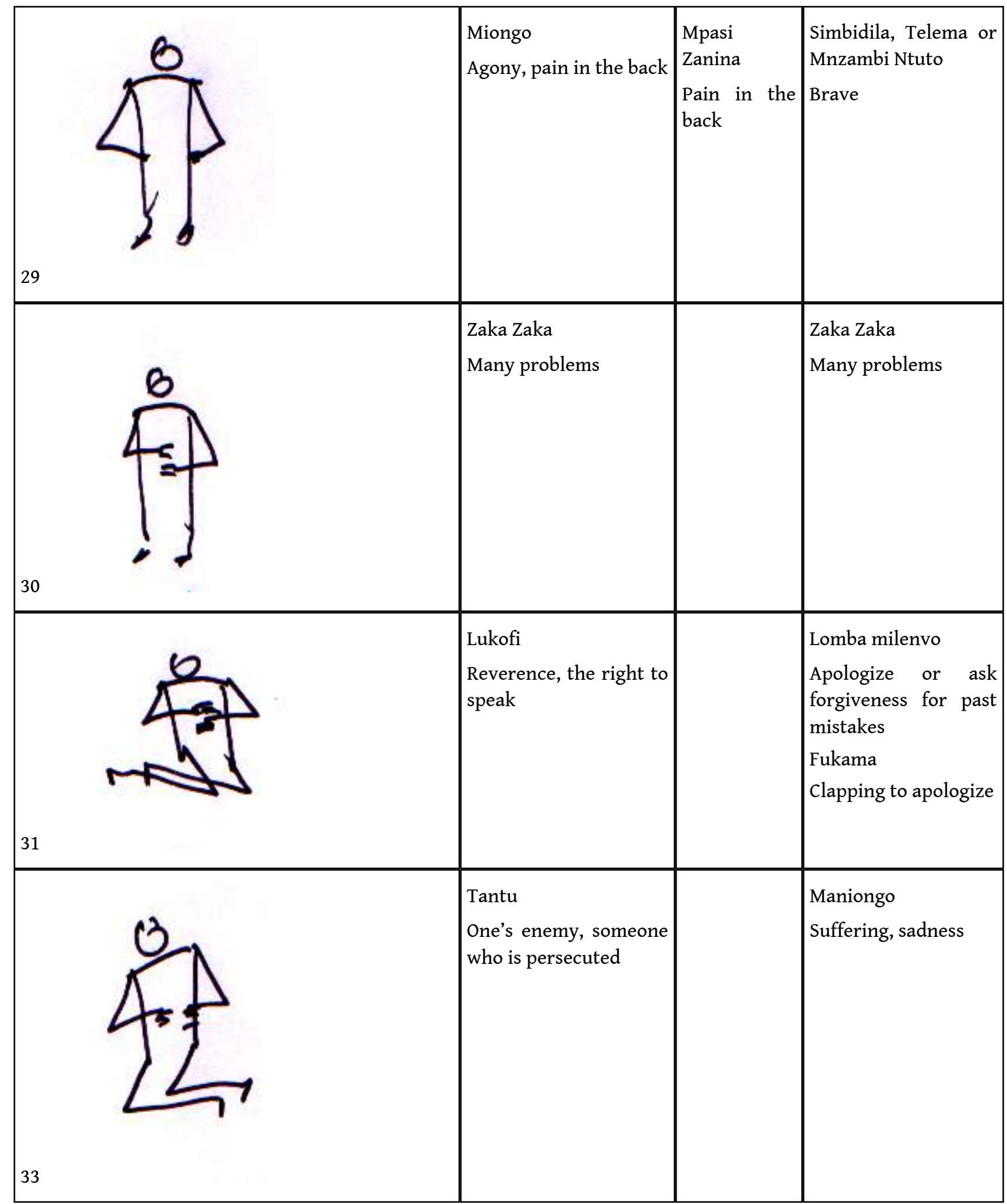

53 As evidenced by the array of gestures and poses, and the detailed meanings each variation carries, body language is and has been an integral part of communication for modern and ancient Bakongo. The multi-dimensional expressions of this range of actions, emotions and religious understandings systematically complement and interact with the other forms of Kongo graphic writing explored in this work. 


\section{NOTES}

1. Nancy Bonvillain, Language, Culture, and Communication, p. 29.

2. Vansina, Oral Tradition as History, p. XII.

3. Ibid., p. 3.

4. Thompson, The Four Moments of the Sun, p. 131.

5. Interview with Mayifwila Rafael Rivals, summer 2002.

6. Ibid.

7. Ibid.

8. Childers, Joseph., and Gary Hentzi. The Columbia Dictionary of Modern Literary and Cultural Critic, p. 185.

9. Interview with the priest and ethnographer Matondo Ngo Blaise, Mbanza Kongo, Angola, 2002.

10. Interview with the prophet of Mpeve a Longo church Mayifwila Rafael Rivals and the priest Botanical House of Mbanza Kongo Francisco Lusolo, Mbanza Kongo Angola, August 2002.

11. See FuKiau, Self-Healing Power and Therapy, p. 116.

12. Thompson, "Communication from Afro-Atlantic." Class lecture, History of Art, Yale University, September 23, 1999.

13. Interview with the chief and priest Ntino Nzaku Nevunda and traditional priest Simão Kwanzambi Mundele, Mbanza Kongo Angola, April 2003.

14. Introduce note on Simbi means master of the fist circle, circle of protection. The holding power that keep unified everything on earth and the universe things and leaving being together.

15. Interview with Ntino Nzaku Nevunda, Mbanza Kongo Angola, April 2003.

16. See Thompson, Le Geste Kongo, pp. 168-69. He associate this gesture with the meaning " to deplore" or "to cry."

17. Thompson, "Communication from Afro-Atlantic." Class lecture, History of Art, Yale University, September 23, 1999.

18. Interview with Simão Kwanzambi Mundele, Mbanza Kongo, Angola, April 2003.

19. Interview with Francisco Lusolo, Mbanza Kongo Angola, March 2002.

20. Interview with Ntino Nzaku Nevunda Mbanza Kongo, April 2003.

21. Interview with Nsenga Alabertina representative of the Black Church in Africa (INAF) Mbanza Kongo, September 2002.

22. Interview with Ne Lusimana Zola of the church BDK in Mbanza Kongo, August 2002.

23. Bundu dia Kongo know under the letter BDK a traditional church that claim that the religious practices are one-hundred percentage base in traditional Kongo religion back to the fifteen century.

24. Mpeve a Nlongo mean in Kikongo the guardian spirit that is only engage through one person at the times in the congregation of religious call.

25. Botanical House of Holly Spirit is a variation of traditional medicine base on the knowledge of Bimbenina (plants) as kind of Simbi manifestation.

See FuKiau, Self-Healing Power., pp. 118-124.

26. See FuKiau, Kongo Cosmology, pp. 120, and 125-26.

27. Ibid., p. 125.

28. Ibid., p. 126.

29. K. K. Bunseki FuKiau Lecture Symbols and Ancient Kongo Pictography, RISD, February 2002.

30. Interview with BDK members, Mbanza Kongo, Angola, 2002.

31. Interview with Ntino Nzaku Nevunda, Mbanza Kongo, Angola, 2003.

32. Cavazzi, Istorica descrizione de' tre regni Congo, p. 162.

33. Ibid., pp.162-63. 
34. FuKiau, Self-Healing Power and Therapy, p. 114.

35. Interview with BDK members, Mbanza Kongo, Angola, 2002.

36. Interview with Ntino Nzaku Nevunda, Mbanza Kongo, Angola, 2003.

37. Interview with Matondo Alfonso (Master Bonga), ceramic artist and Adão João Tomás Vista (Ntetembwa), painter. August 8, 2002.

38. Thompson, The Four Moments, p. 58.

39. Ibid., p. 62.

40. Interview with Matondo Alfonso (Master Bonga), ceramic artist and Adão João Tomás Vista (Ntetembwa), painter. August 8, 2002.

41. Personal conversation with Robert Farris Thompson, summer 2001.

42. Ntino Nzaku Nevunda, Mpeve a Nlongo and Bundu dia Kongo.

43. Personal conversation with Ntino Nzaku Nevunda, March 2003.

44. Personal conversation with members of Bundu dia Kongo, summer 2002.

45. Personal conversation with Simão Kwanzambi Mundele, March 2003.

46. K. K. Bunseki FuKiau, "Bidimbu ye Nsonokolo za Kongo" Class Lecture, History of Art, Rhode Island School of Design, January 23, 2003.

47. Ibid.

48. See Barbaro Martinez-Ruiz, Odantalan 02, p. 98.

49. Thompson, The Four Moments of the Sun, pp. 38-39.

50. Ibid., p. 244.

51. Cavazzi, Istorica descrizione de' tre regni Congo, pp. 277-278.

52. Ibid, p. 277.

53. Thompson, Four Moments of the Sun, p. 168.

54. Ibid, p. 168.

55. Cavazzi, Istorica descrizione de' tre regni Congo, 1 vol, pp. 288-89.

56. Interview with Ntino Nzaku Nevunda, Mbanza Kongo, Angola, April 2003.

57. Interview with Francisco Lusolo, Mbanza Kongo, Angola, May 2002.

58. Interview with Simão Kwanzambi Mundele, Mbanza Kongo, Angola, April 2003.

59. Cavazzi, Istorica descrizione de' tre regni Congo, 1vol, p. 209.

60. Interview with Francisco Lusolo, Mbanza Kongo, Angola, May 2002.

61. Interview with Ntino Nzaku Nevunda, Mbanza Kongo, Angola, April 2003.

62. Interview with Francisco Lusolo, Mbanza Kongo, Angola, May 2002.

63. Cavazzi, Istorica descrizione de' tre regni Congo, 2 vol, p. 140.

64. Personal conversation with Robert Farris Thompson, 2002.

65. Thompson, "Communication from Afro-Atlantic." Class lecture, History of Art, Yale University, September 23, 1999.

66. Thompson, Four Moments of the Sun, p. 235.

67. Other meanings of this pose gathered in Mbanza Kongo include: frequent usage during religious performance when the priest is positioned to block the sight of the people inside the room from the radiation of spiritual force from the Nkisi that are located in the Nso a Nkisi; by the name of Lukumano, Francisco Lusolo and Mayifwila Rafael Rival state that this gesture means crying, responsibility, and to call the members of the community for help.

68. Thompson, The Four Moments of the Sun, page 167.

69. Interview with Ntino Nzaku Nevunda, Mbanza Kongo, Angola, April, 2003.

70. Thompson, The Four Moments of the Sun, p. 169.

71. Personal interview with Ntino Nzaku Nevunda, Mbanza Kongo, Angola, 2002.

72. Thompson, The Four Moments of the Sun, p. 129. 


\section{ABSTRACTS}

This lecture will focus on the agency of body language, gesture, and performance as cultural entities motivating responses and interpretations of cultural principles in the Kongo, in the Atlantic world. Barbaro Martinez-Ruiz will argue that many kinds of body language can be seamlessly integrated into visual and aural communicative techniques, which he refers to as graphic writing systems. Such systems also include proverbs, mambos, syncopated rhythms, a large variety of written symbols and oral traditions that are incredibly rich sources of cultural and social histories, religious beliefs, myths, and other expressions of the shared Bakongo worldview. The presentation will incorporate key examples gathered through fieldwork among the Kongo people in northern Angola and the southern Democratic Republic of the Congo, as well as within Kongo-based religious traditions in the Caribbean and North America. The lecture will explore fundamental questions of cognition, memory, and identity from the vantage point of multicultural studies, visual culture, art history, and anthropology.

Cette intervention porte sur l'agencement entre langage corporel, gestes et performance, en tant qu'éléments inhérents à la culture des Kongo. L'auteur montre comment ces différents modes d'expression s'intègrent sans rupture notable. De tels ensembles incluent aussi des mambos, des rythmes syncopés, ainsi qu'une très grande variété de symboles, écrits ou de tradition orale, partagées par les Bakongos. La présentation incorpore des exemples clés du peuple Kongo à travers le monde, tant dans le nord de l'Angola que dans le sud de la RDC, tant dans les manifestations religieuses de l'intérieur du Kongo que dans les Caraïbes ou en Amérique du Nord. Cette lecture explore des questions de cognitivité, de mémoire et d'identité, prenant en compte tant le point de vue multiculturel, que la culture visuelle, l'histoire de l'art et l'anthropologie.

\section{AUTHOR}

\section{BARBARO MARTINEZ-RUIZ}

Bárbaro Martínez-Ruiz est Historien d'art spécialisé en pratiques artistiques, visuelles et religieuses d'Afrique et des Caraïbes. Né et grandi à Cuba, il a enseigné Histoire de l'art à l'Havana au High Institute of Art pour cinq ans avant d'aller aux Etats-Unis. Il a dirigé des expositions sur l'art africain contemporain et présenté son travail multimédia à New York et Alabama. Il a obtenu son doctorat au département d'Histoire de l'art à Yale University en 2004. Il est maintenant assistant professor au Department of Art and Art History at Stanford University menant des recherches sur African Graphic Writing Systems in the Kongo world. 